\title{
ERATO 加藤核内複合体プロジェクト中間評価報告書
}

\author{
【研究総括】加藤 茂明 （東京大学分子細胞生物学研究所／教授） \\ 【評価委員長】石井 俊輔 （理化学研究所筑波研究所／主任研究員） \\ 【評価委員】五十嵐 和彦（東北大学大学院医学研究科／教授） \\ 水島 昇 (東京医科歯科大学大学院医歯学総合研究科／教授) \\ 宮浦 千里（東京農工大学大学院共生科学技術研究院／教授）
}

\section{評価の概要}

ERATO 加藤核内複合体プロジェクトは、核内における情報制御の基本的仕組みが 核内複合体の機能として備わっているとする加藤研究総括による独創的かつ壮大な仮 説に基づき、新規核内複合体の単離精製を行うと共に、得られた複合体の機能解析を 推進するものである。本研究により、細胞内シグナル伝達のクロストークの基本原理 が明らかにされるものと期待され、大いに推進すべき研究プロジェクトである。

競争の激しいシグナル伝達研究、転写研究の分野の中で、独創性を発揮し、高いレ ベルの成果を生み出すことは並大抵のことではないが、独自のアプローチと抜群の指 導力・運営力により、予想を超える成果を生み出し、着実にその構想の実現に向かっ て進んでいる。また、本プロジェクトはこれらの成果により関連分野において世界を 先導している。これら成果の中には学術的に新たなパラダイムを提供する優れた研究 成果がいくつも認められるが、特筆すべきは、これらは単なる学術的なインパクトの 創出に留まらず、社会的、産業的インパクトをも生み出していることである。中でも、 ダイオキシンの内分泌擋乱作用の解明やエストロゲンと骨粗鬆症との関連に関する研 究成果は学術的にも、社会的にも素晴らしい成果であり、これらの研究成果が国民に もわかりやすい形で示されている点でも高く評価される。

本プロジェクトでの取り組みを構想、運営、研究進渉状況について中間評価ヒアリ ングを行ったが、どれをとっても秀でたレベルにあり、これらが優れた研究結果に繋 がっていることをうかがわせるものであった。また、未公表の研究成果の中にも優れ たものが多数見受けられ、残る期間の研究にも十分期待できるものである。

これらを総合的に判断し、加藤プロジェクトの活動は高く評価されてしかるべきも のであるというのが評価委員の一致した意見である。残る 2 年間の研究期間を存分に 活用し、さらなる大きなインパクトを生み出して欲しい。 


\section{1. 研究プロジェクトの設定および運営}

\section{1-1．プロジェクトの全体構想}

ERATO 加藤核内複合体プロジェクトは、研究総括である加藤茂明博士が、自身 の CREST ${ }^{1}$ ならびに SORST ${ }^{2}$ で得た知見を手がかりとして、細胞内のグローバルな遺 伝情報管理ネットワークの全貌解明を目指寸ものであり、「細胞内の強調的かつ厳格に 制御される機能統御の仕組み」を明らかにしようとする研究である。巨大核内複合体 が複雑な情報処理、管理の場として機能し、個別のシグナル伝達経路を統合し、遺伝 情報管理ネットワークを構築しているとする新しい独自の考えに基づき、当該機能を 有する超巨大複合体の同定と解析を試みている。複合体の機能と各種情報伝達因子と の関係を多角的に検証することにより、上述の遺伝情報管理ネットワークの全貌を明 らかにしようとするものである。

本プロジェクトは本研究構想に基づき、戦略目標「個人の遺伝情報に基づく副作 用のないテーラーメイド医療実現のためのゲノム情報活用基盤技術の確立」のもと、 2004 年 10 月に発足した。超巨大複合体の単離・解析により新たな情報処理ネットワ ークの存在を明らかにしようとする本構想は、これまで個別に研究が進められがちで あった個別のシグナル伝達経路を統合し、複雑な細胞なシグナル伝達の包括的な理解 を目指すものであり、ERATO で推進するに相応しい、独創的かつ壮大な構想である と評価される。

\section{1-2. プロジェクトの枠組みや研究体制、および研究活動の状況}

本プロジェクトの研究は、核内複合体グループ・核内シグナルクロストークグル ープ・高次機能グループの 3 つグループにより推進されており、これらの研究体制 は全て加藤総括の本務先である東京大学分子細胞生物学研究所内に設置されている。 各研究グループでは多彩な研究手法を有機的に組み合わせて研究を推進し、また、各 グループ間の成果を互いに活用する方針の下、融合的な研究を推進している。本プロ ジェクトの構想には核内複合体研究により世界を切り開く創造性と独創性が認められ、 加藤総括による戦略的かつ優良なプロジェクト運営により構想が実現に向けて大きく 動き出していることが印象的である。

生命科学と工学の融合も意図され、例えば、複合体ソーターの開発などの挑戦的 な課題も設定されている。生命科学と工学系の多様な研究者を集め、梁山泊的な雰囲 気を持ちながらも、全体として一つの方向にベクトルが向からように巧みにアレンジ がなされている。これらのテーマ設定、異分野の研究者の積極的な取り込みが、加藤 総括の絶妙なマネジメントと相まって、予想を大きく超える成果に繋がっているもの であり、研究プロジェクトの設定および運営に関しては、特に優れて的確かつ効果的 であると認められるものである。

本プロジェクトは発足後 3 年を経過したところであるが、特筆すべき成果を数多 く生み出している。これらの成果は Nature や Cell などの世界のトップジャーナルに

\footnotetext{
1 研究領域「生命活動のプログラム」研究課題「遺伝情報制御分子としてのステロイドレセプター」平 成 9 年から平成 14 年まで

2 研究課題「遺伝情報制御分子としてのステロイドレセプター」平成 14 年から平成 16 年まで
} 
掲載されるなど、純粋な基礎研究としても高く評価される成果であるが、それだけに とどまらず、医療分野、環境分野などの分野にも大きなインパクトを与えており、近 い将来にこれらの分野の研究に応用される可能性の高いものである。残る研究期間で も十分に高い成果が期待できる。

〔研究プロジェクトの設定および運営と今後の見込]

a+ （特に優れて的確かつ効果的である）

[研究活動の状況]

a+ （特筆して望ましい研究展開を示しており、今後にもさらに期待できる）

\section{2. 研究成果}

\section{$2-1$. 核内複合体グループ}

本グループでは哺乳類細胞の発現・精製系を有効に利用しながら、多方面からの アプローチにより、核内受容体巨大複合体の同定及び精製を進めている。いずれも、 専門性と技術力を必要とする実験であるが、巧みな戦略を取り、成功を収めている。 研究開始時にはその存在すらほとんど不明であった超巨大複合体についても、その存 在が明らかにされつつあり、そのいくつかについては同定と機能解析に成功している。 また、超巨大複合体ソーターの開発などの挑戦的な課題でも着実な進渉が認められる。 以下に詳細を述べる。

新規核内複合体の機能解析に関しては、女性ホルモン受容体 ER $\alpha$ の転写共役因子 p68, p72 RNAヘリカーゼの機能解析を行い、エストロゲンが転写制御を行うとともに、 miRNA のプロセッシングを介して、様々な生体機能を制御する可能性を示している。 これは、これまでの核内受容体とその共役因子の常識を超える研究成果である。また、 血球分化を規定する新規核内受容体転写共役因子の探索としては、未分化血球系がん 細胞である HL-60 細胞のレチノイン酸による分化誘導の系をモデル系として用いて、 HL-60 細胞の顆粒球への分化促進因子として新規ヒストンメチル化酵素 RAR $\alpha$ -interacting granulocytic inducer (RAIGIN)複合体を同定した。この成果は今まで分子レ ベルでの詳細が不明であったレチノイン酸誘導性血球分化を解明するブレークスルー となるとみられる。

超巨大複合体取得の試みとしては、核内複合体をセルソーターの原理を応用して単 離する目的で、新しいセルソーターの開発を行っている。従来のセルソーターの能力 を考えると、複合体をソートするために必要なスペックまで装置を改良するのはチャ レンジングな試みであったが、本グループでは、緻密なアプローチを取り、複合体ソ ーターの開発に必要な素過程を良く分析し、ソーターの感度を大幅に上げることに成 功している。既に相当程度の性能を達成しているようなので、この方法が中間的な大 きさのオルガネラ（リボソームやミトコンドリアなど）の単離に有効であれば、それ も産業応用されうる成果である。利用可能なリソースの中で何を達成できるかが良く 検討されているが、本装置に関してもオルガネラソーターへの応用等、様々な可能性 を含めて検討をお願いしたい。 


\section{2-2. 核内シグナルクロストークグループ}

本研究グループでは核内複合体を介した複数の核内シグナルのクロストークに焦点を 定め、ユニークな研究が計画されている。このグループからは胆汁酸とグルカゴン、 ダイオキシンとエストロゲン間のクロストーク機構の解析などオリジナリティの高い 成果が創出されており、それぞれが新しい概念を提示する成果となっている。扱う因 子が重要な生理活性物質や環境ホルモン等であるため、これらの新しい知見は疾患や 環境問題に直結するものである。特にインパクトの大きい、ダイオキシンとエストロ ゲン間のシグナルクロストーク機構の解明について以下に評価を述べる。

ダイオキシン受容体とエストロゲン受容体のクロストークを担うユビキチンリガーゼ 複合体の解析については、ダイオキシン受容体 AhR がリガンド依存的にユビキチンリ ガーゼ複合体を形成して、エストロゲン受容体やアンドロゲン受容体のタンパク質分 解を促すことを発見している。これまでは性ホルモンの転写制御などにより撹乱作用 を示すことが想像されていたが、ダイオキシン受容体が、エストロゲン受容体分解の ためのアダプターとして機能するという新たな知見は、基礎科学分野のみならず、環 境ホルモンの作用機序を理解する上で、極めて重要な知見である。タンパク質の分解 は生体制御の重要な過程であることが知られているが、分解に関わる遺伝子は 1000 近くあると見積もられており、それ故に中心的役割を担っているユビキチンリガーゼ 複合体の活性制御についてはほとんど知られていない。そのような状況の中で今回の 成果はユビキチンリガーゼの活性が受容体へのリガンド結合によって制御されること を明らかにしたものであり、将来のタンパク質分解研究のマイルストーンとなるであ ろう画期的な発見である。また核内受容体の多くが他のユビキチンリガーゼと複合体 を形成しているという知見は、脂溶性リガンドが転写と分解の双方を制御しうるとい う、これも画期的なコンセプトを提唱寸ることになる。残る期間も着実に研究を推進 することにより、大いに発展することが期待される研究テーマである。

このように、本研究グループに関しても着実に研究が進渉しており、今後も大きな成 果が期待できる。

\section{$2-3$. 高次機能グループ}

本グループでは、コンディショナルノックアウトマウスを用いてエストロゲン受容 体機能の解析を推進しており、破骨細胞特異的エストロゲン受容体（ERQ）欠損マウ スを作出することにより、骨代謝における女性ホルモンの作用機構を詳細に解明した。 これまで、エストロゲンの骨代謝作用メカニズムと骨粗鬆症発症機構は不明な点が多 かったが、本研究により破骨細胞がエストロゲンの標的細胞であることが解明され、 エストロゲンが破骨細胞のアポトーシスを誘導し、骨量維持を行っていることが明ら かとなった。この成果は、閉経後の骨粗鬆症発症メカニズムの一端を明らかにしたと いう意味で、特筆すべき成果である。疾患の予防や診断の基礎となり、医療への応用 へと繋がることが大いに期待される。

上記以外にも、マウス遺伝学とショウジョウバエ遺伝学を駆使して核内複合体に関 する個体レベルでの研究を推進しており、成果が上がり始めている。条件的ノックア ウトマウスの対象としている因子はいずれも本プロジェクトで同定されてきたもので 
あり、いずれも独自性の高い研究となるであろう。本研究グループからも核内複合体 と病態との関連について優れた成果が上がっていると評価したい。

以上、3グループの成果を総合的に考慮し、研究成果が科学的側面、産業・社会的 側面の双方の観点から秀逸であるとの意見で評価委員の意見が一致した。

〔研究成果の現状と今後の見込〕

a+（成果として秀逸であり、今後にもさらに期待できる）

\section{3. 総合所見}

全体的に、研究成果の質、量共に特筆す心゙きものがあり、世界的にも有数のプロジ エクト研究であるといえる。加藤総括の核内複合体に焦点を絞った本研究はその手法、 切り口において独創性が高く、画期的なコンセプトを提示することに成功している。 従来の生化学、分子生物学的な手法に加えて、動物個体を利用した研究手法を組み合 わせることで、信頼性の高い成果を生み出していることもこれらの成功を力強く後押 ししている。これら研究成果の中には、エストロゲンと骨粗鬆症の問題やダイオキシ ンと内分泌擋乱作用など、社会的に見ても重要な問題も含まれており、これらは既に Nature、Cell を初めとするトップジャーナルに発表されている。また、中間評価での 発表から判断して、未発表の研究成果の中にも、発表済みの成果に匹敵する、あるい は超えると思われるものが多数存在し、本プロジェクトが極めて高い水準で順調に運 営されていることがうかがえる。ノックアウトマウスなどの動物個体の解析には長期 間を要するため、5 年間のプロジェクト内では閒に合わない実験もあると予想される が、今後も力強く研究を推進すれば、さらに大きなブレークスルーが生み出されるも のと期待できる。核内複合体ソーターの開発に関しては必要スペックに向けて感度を 大幅に向上させることに成功しており、現状のスペックでも産業利用可能な分野が有 りそうなので、産業化へ向けた試みにも是非チャレンジして欲しい。

以上のように、本プロジェクトは予想を超える卓越した成果を上げており、関連分 野において世界をリードしている。発表論文も一流紙に掲載されるなど、パブリケー ションストラテジーにおいても大変優良である。また、これらが結果として若手研究 者の育成に役立っている。

これらを総合的に判断し、本研究プロジェクトの研究実施状況は卓越した研究水準 にあるというのが、評価委員の一致した意見である。

〔総合評価〕 A+ (卓越した研究水準にある)

以上 